\title{
7 he Santiago de Compostela pilgrim ROUTES: THE DEVELOPMENT OF EUROPEAN CULTURAL HERITAGE POLICY AND PRACTICE FROM A CRITICAL PERSPECTIVE
}

\author{
Sven Grabow \\ Wellington, New Zealand
}

\begin{abstract}
Using the case study of the Council of Europe's European Cultural Routes Project, this article examines if and how far supra-national rhetorics of cultural openness, inclusivity, and diversity become reality in terms of actual cultural heritage projects. Against this background, it conducts a critical examination of what is considered one of the flagships of European supranational cultural heritage projects, the Council of Europe's Santiago de Compostela Pilgrim Routes. It focuses on the specific implementation of the Council of Europe's supra-national message of cultural heritage in this project and in its accompanying guidebook. By placing the project in its historical context and comparing it to later additions to the European Cultural Routes Project, this article reflects on the development of a pan-European cultural identity paradigm over the last two decades.
\end{abstract}

Keywords: Council of Europe, cultural heritage, cultural identity, culture policy, European Institute of Cultural Routes, pilgrim routes, St James, Santiago de Compostela

\section{INTRODUCTION}

To the surprise of many, geographical and geological Europe is not a continent at all - that is a landmass separate from other such masses and entirely surrounded by water. In the true meaning of the word it is only possible to distinguish five continental units: America, Australia, Greenland, Antarctica, and a large block consisting of Europe, Asia, and Africa. Even if we widen this understanding to include any landmass mostly separated from others by water, still it would not provide any grounds on which to set apart Europe from Asia. Even at its narrowest point, around $2000 \mathrm{~km}$ of land separate the Black Sea from the White Sea. In fact, however relaxed a geographical or geological definition for a continent we choose to apply, Europe remains a peninsula forming the westernmost part of Eurasia. As summarized poignantly by Wallace (1990:7): 'Europe is a geographical expression 
with political significance and immense symbolic weight, but without agreed boundaries'. The forces defining and binding Europe as an imaginary unit are not to be discovered between the contour lines of geographical or geological maps. Instead, Europe's recognition and status as a continental unit must be considered as predominantly social in character. More to the point, it is cultural and historical links, the stories that people relate, that provide the grounds on which Europe becomes Europe. For example, Turkey is often regarded as not part of Europe because most of its territory is not located on the European landmass. Yet, as pointed out by Dobson (2004:5), no part of Britain or Eire is part of this landmass either. So what and where is Europe?

Since antiquity, the idea of Europe and European-ness has undergone numerous re-evaluations and redefinitions (see Delanty 1995). The adjective 'European' was first used by Pope Pius II (AD 1405-1464). However, as an ideologically ill-defined concept (Graham 1998a:3), it did not come into wider use before the Renaissance (Dodd 2002:189), reappearing with renewed vigour at the end of the seventeenth and beginning of the eighteenth centuries as 'part and parcel of an early secularisation that sought to replace Judaeo-Christianity as the continent's common cultural focus' (Graham 1998b:3; see also Wilson and van den Dussen 1993:chap. 3). During the nineteenth and twentieth centuries the idea of Europe and European changed with increased speed. Throughout this time, the contrasting faiths, cultural traditions, attitudes and historical experiences ensured a vast array of distinct identifications and feelings of $u s$ and them to be found all across Europe (Nugent 1989:5-6; Zeff and Pirro 2001:1). In particular, Europe's wars and armed conflicts during the nineteenth and twentieth centuries provided the impetus for the continuous redrawing of numerous geographical and socio-cultural frontiers (see Broers 1996; Elliot 1992), bringing with it new concepts of Europe (e.g. Napoleon's Europe, Hitler's Europe, Cold-War Europe). To quote Morin (cited in Bellier and Wilson 2000:13, original emphasis):

[m]odern Europe is the fruit of a perpetual metamorphosis: from Europe of the states to Europe of the nation-states, from Europe of the balance of power to Europe of deregulation and outburst, from merchant Europe to industrial Europe, from Europe of the Apogee to Europe of the Abyss, from Europe master of the world to Europe region under control. So its identity is not defined despite metamorphosis but within metamorphosis.

With the idea of Europe being dependent on the historical and cultural environment within which it is pronounced, we find not one overarching definition of Europe through time, not only one story that people relate to, but a multitude of changing paradigms (see Stråth 2002 for an in-depth discussion of the historical concept of 'Europe'). These redefinitions/re-conceptualizations represent an important focus for scholarly research, ranging from politics and economy to cultural studies. To quote Paasi (2001:8):

[f]or almost 3000 years ideas of Europe have been characterized by difference, whether geographical and/or mythological. One challenge for research 
is to deconstruct the processes in which the ideas of difference have been created, and to analyse what has been included and excluded at different times in different spatial contexts.

At the chronological end of this list of large-scale reconceptions of Europe so far, and representing 'the first institutional self-identification of Europe' (Kenny 2007:171), is the idea of a united pan-European Europe - be that in political, economic, or cultural terms - as envisaged and promoted by supra-national bodies such as the European Union (henceforth EU) and the Council of Europe (henceforth $\mathrm{CoE}$ ). It is this latest large-scale 'reinvention' of Europe, depending, as did its predecessors, on particular discursive interpretations rooted in 'an expanded sense of European identity' (Heffernan 2001:29), that is the focus of the following discussion. This critical examination will centre on one particular manifestation of the idea of a culturally united Europe, namely the Santiago de Compostela Pilgrim Routes (henceforth SCPR) as developed as part of the CoE's European Cultural Routes Project (henceforth ECRP).

Before continuing, however, a brief comment must be inserted. Focusing on a particular institutional paradigm of an expanded Europe united in its cultural past, the following examination has recourse to policy documents, as well as to the concrete manifestation of the project under consideration on the ground. It is in this context that it could be argued that such documents and projects are never the result of univocal decisions, and, thus, should not be taken as expressing the views of the organization's members as a whole. Also, large organizations like the CoE usually lack the ability to control rhetorics used or decisions made by its constituent parts, its partners, or even its members. Nonetheless, even though the CoE's members may have diverse views, such documents and projects must be argued to represent the 'official' views of the CoE, and, thus, they must be held accountable for their choices, in the same way that a political party's manifesto, even though every single party member may not endorse it, is held to represent the official policy of the party.

\section{The Council of Europe and the European Cultural Routes Project}

The overriding relevance of the $\mathrm{CoE}$ is determined by its institutional history, context, and objectives. Founded in 1949, the CoE represents Europe's oldest supranational politico-cultural institution, an umbrella organization for the development of society in Europe through cultural means, as well as the 'prime instrument' for the safeguarding and strengthening of European cultural heritage (see CoE 2003a). Its remit extending far beyond the 27 member states of the EU, it currently incorporates 45 countries with its headquarters in Strasbourg, France (see Huber 1999 for an in-depth history of the CoE). The framework for the CoE's work on education, culture, and heritage is the European Cultural Convention (CoE 1954). Signed by all its member states, this document encourages the study of 'European history and civilisation' (CoE 1954: 2). The independent CoE is not equivalent to the EU. Instead, the two supra-national organizations are both distinct and complementary. Even 
though not all of the CoE's members are part of the EU, all present-day EU member states are also members of the CoE. In fact, while not being a prerequisite, no country has ever joined the EU without first having been member of the CoE (2004a). As emphasized by Walter Schwimmer (2003), Secretary General of the CoE, in an address entitled 'The Council of Europe at the Dawn of the 21st Century', the CoE understands its mission to be to culturally prepare countries for membership of the EU. This is the more relevant in that, whilst always in the remit of the CoE, culture is a relatively new, and limited, extension to EU competences. As such, the CoE and its projects represent an important focus for the exploration of supra-national modes of constructing pan-European heritage.

In terms of its underlying cultural policy philosophy, as stated on its webpage (CoE 2004a; also CoE 2004b), the CoE perceives its main role to be to 'promote awareness of a European identity based on shared values and cutting across different cultures'. To go into more detail, as re-emphasized in the CoE's (11.01.1993:2) report of the second meeting of the advisory committee on European cultural routes, its mission is 'to use cultural co-operation to promote grassroots experiments in interculturality, foster the concept of cultural identity as the simultaneous sharing of several identities, and encourage education for democracy, tolerance and solidarity'. Or, in the words of Schwimmer (2003), for this cannot be overemphasized, the CoE's raison d'être is, and has been in the past, to 'combat social exclusion and cultural isolation'. It is in this understanding that the CoE recalls the EU's official motto of 'unity-in-diversity' (Pantel 1999).

In terms of actual cultural heritage measures on the ground, the ECRP represents one of the CoE's most established. As stated by Michel Thomas-Penette, current Director of the ECRP, in an interview with the author, ${ }^{1}$ the CoE considered itself rather unsuited to deal in a concrete way with the very strange concept of cultural heritage, so in order to conduct the practical work of the construction of a united Europe based on culture it invented, as a kind of support, the ECRP and the European Institute of Cultural Routes (henceforth EICR) in 1987 (see also CoE 24.03.1994:2). This development was regarded as particularly important in that, as stated on the CoE's webpage (2003b), the subject's (i.e. culture) 'pedagogy had largely been led on the theoretical level by the Council of Europe'. As such, the ECRP's purpose became to evolve around the theme-based creation, implementation, and development of operational cultural heritage networks also called itineraries - across Europe's regions. By interconnecting cultural heritage sites under themes considered typically European, and this way explain 'the influences, exchanges, and evolutions which have forged the European identity in its unity and diversity' (CoE 27.04.1997:1), European Cultural Routes would allow those travelling along them to rediscover Europe's common heritage through travel (see EICR 2003:1).

\section{The Santiago de Compostela Pilgrim Routes (SCPR)}

Going hand-in-hand with the establishment of the ECRP and EICR, the SCPR represent the first and, thus, oldest of the European Cultural Routes (henceforth 
ECRs). The SCPR's relevance in the context of an examination of a particular manifestation of the idea of a culturally united Europe arises from a number of factors. Firstly, representing the oldest ECR, as well as the first officially awarded certification as a Major Cultural Route of the Council of Europe, the CoE and EICR had two decades during which to shape the SCPR's cultural heritage character to their liking. As such it must be assumed that the SCPR represent one of the most telling crystallization surfaces for the CoE's notion of a common European cultural heritage paradigm. Secondly, the CoE itself emphasizes the SCPR as distinct. To quote the CoE's (2003b) webpage, '[a]lthough they are included amongst the Council of Europe's Cultural Routes, the Santiago de Compostela Pilgrim Routes are unquestionably a special case'. Now a Leitmotiv for all present and future ECRs, '[t]he Santiago Pilgrim Routes served initially as a source of inspiration, then became the reference point for the development of future activities' (EICR 2005:1), and they 'symbolise first and foremost the process of European construction' (CoE 01.10.1996:6). In short, the ECRP is considered a 'flagship programme' (CoE 17.03.1994:3) for 'enhancing cultural pluralism' (CoE 20.01.1992:2). In particular, the ECRP aims particularly at the exploration and acceptance of the Other. To quote from a CoE (16.06.1994:10) policy document on how to make culture and tourism complementary through the use of ECRs:

the Council of Europe's cultural routes are a practical, open response to the need to bring together tourism and culture, because they give practical expression to culture in a fundamental experience where the pure act of travelling is transformed into encounter and, in the end, understanding oneself, of others, and of the world.

This rhetorical dedication also finds expression in the fundamental value to which the ECRP claims to adhere. As stated on the CoE's webpage (2003a; see also Thomas-Penette 1999:7), the ECRP offers:

a tangible and visible illustration of both the overall unity and the inherent diversity of European culture, corresponding perfectly to the aims and ideals of strengthening European identity while respecting to the full the cultural heritage and the beliefs of others.

As the EICR (2005:1) confidently asserts in its SCPR information leaflet: 'the Santiago Routes serve both as symbol, reflecting over one thousand years of history, and as a model of cultural co-operation for Europe as a whole'. It is in particular openness, inclusivity, and diversity in terms of faith that are writ large in the ECRP's approach to the Other. As stated by the EICR (2005:1), it aims 'to promote intercultural and interreligious dialogue through a better understanding of European history', providing 'people of varied background, believers and non-believers, with an opportunity to gather together' (EICR 2005:1). As such, the CoE's ECRP can be argued to display similarities to the EU's wider overall emphasis on the separation of the religious and social sphere while supporting religious pluralism in general. 
In summary, the institutions responsible for its implementation and discursive character understand the SCPR to represent a 'modèle de coopération culturelle pour la Grande Europe du futur' (EICR 2005:1; see also Thomas-Penette 2003). In the words of José M. Ballester (2002:11), Head of the Cultural Heritage Department of the CoE, from his introduction to the official SCPR guidebook, the SCPR actively counteracts the 'dangers qui planent sur le processus d'union et de construction actuellement en cours: intolerance, racisme, xénophobie, violence, exclusion sociale'.

\section{St James: Legend and medieval propaganda}

The SCPR's thematic focus lies in the medieval movement of Christian pilgrims along a network of routes to the alleged resting place of the Apostle St James the Greater (Spanish: Santiago) in the cathedral of Santiago de Compostela (henceforth $\mathrm{SdC}$ ) in north-western Spain. Yet, who was this St James that the CoE chose as a theme to function as the flagship for its ECRs, and, thus, for its common European cultural heritage paradigm?

The legend of St James has many variants, its historical evidence ranging from the fantastic to the contradictory. In the following, I summarize the most widely recognized version (see Fletcher 1984; Gitlitz and Davidson 2000). His legend begins two millennia ago, when, shortly before his crucifixion, Jesus divided up the known world among his Apostles to spread the Christian faith. Legend has it that James the Greater was assigned the Iberic peninsula. There he spent some years preaching before returning to Jerusalem where he died around AD 44, the first Apostle to be martyred. The story goes that his companions placed his body in a ship that eventually ended up at the Spanish north-west coast, where he was buried on a nearby hill. There his tomb remained forgotten for almost eight centuries, until it was allegedly rediscovered in $\mathrm{AD}$ 814, and the remains declared genuine by Bishop Teodmiro of Iria. A shrine was then built to hold them.

However, it was not until three decades later that the 'cult of Santiago' (Luard 1998:79) began. It was in AD 844 - after the saint is said to have miraculously appeared and taken command of the Christian forces fighting a Muslim army at the Battle of Clavijo, ${ }^{2}$ riding through the skies on his white charger and 'wielding a bloody, dripping sword, surrounded by decapitated infidels' (Graham 1998a:24) that a church was built at the place of the shrine. During the following centuries this church was transformed into one of the most elaborate cathedrals of medieval Europe, that of SdC. It is, however, only in the context of the Islamic 'occupation' of the Iberian Peninsula that the legend of St James, its growing popularity and ideological connotations, can be understood as part of a wider paradigmatic whole. Without it, St James might not even exist.

In the ninth century, the time of the alleged rediscovery of St James's remains, the Moorish kingdom of Al-Andalus controlled most of Iberia, with only the Spanish regions of Asturias and Galicia remaining unconquered. With Spanish military forces dwindling in numbers, and at a time when the battle over territory and faith was usually one and the same, Spain's secular rulers were in need of a 
religious fighting figure capable of rallying and uniting Christians from all over Europe under a single banner against Iberia's Muslim rulers. It was then that their eye fell on the mythical figure of the only Apostle allegedly buried on European soil. From this point onwards, Christian politico-military and religious leaders promoted his legend - by, for example, employing professional storytellers - in order to provide a common role (i.e. identity) model, as well as an efficient tool for the wider power politics of the Roman Church (Graham and Murray 1997:393). The gentle and peaceful preacher St James was discursively transformed into Santiago de Matamoros (St James the Moor-Killer), an invincible and vengeful Muslim-slaying Christian warrior, supposedly aiding the Spaniards and their Christian allies at least 40 times in military operations against Muslims (Gibbs 1997:26-27; Luard 1998:81). Effectively a foreign policy tool, Santiago became synonymous with the Christian fight against Iberia's Muslim rulers, and crucial to the 'effective mobilisation' (Graham 1998a:24) of the Reconquista (reconquest) of the Iberian Peninsula as a Holy War. ${ }^{3}$ He became the embodiment of the fight of European Christians and Christianity against European Muslims and Islam. Perhaps unsurprisingly, it was after the final victory over Iberian Islam in AD 1492, its socio-political raison d'être having disappeared, that the cult of Santiago entered a long phase of decline (Graham and Murray 1997:398).

In summary, the ECRP's flagship project, this model for European cultural cooperation, is based on a symbol of medieval politico-religious propaganda revolving around the declared rightful and forceful struggle of European Christians against European Muslims on European soil. It is within this discourse that Europe is defined as an exclusively Christian territory that has to be defended against hordes of infidels washing up against its southern shores and occupying its territory. As such, the selection of the figure of St James can be argued to represent a poor choice for an allegedly multicultural and in particular religiously open-minded mode of constructing pan-European heritage. However, in order to assess the SCPR it is necessary to ask what discursive character the project takes in terms of qualified cultural heritage on the ground?

\section{The SCPR's heritage on the ground}

To date, the SCPR incorporate routes of linearly connected heritage sites passing through Germany, Austria, Switzerland, Hungary, Poland, Slovenia, Croatia, the Czech Republic, Belgium, Luxembourg, the Netherlands, Denmark, Italy, Portugal, France, Spain, and Britain (EICR 2004a; Fig. 1). In order to critically assess the SCPR's cultural heritage discourse in terms of sites on the ground, the following analysis of the SCPR's cultural heritage site discourse employs two of its major routes, namely the interlinking Polish Route and Danish Route. Starting in Gdansk, after passing through Germany, Luxembourg, and France, the Polish Route joins the Route de Danemark, coming down from Århus in Denmark, at the French town of Sauveterre-de-Béarn, from where it leads to SdC. This route was chosen for quantitative analysis on the grounds that, unlike other routes, the Polish/Danish Route ${ }^{4}$ represents a continuous linear path of heritage sites with no 


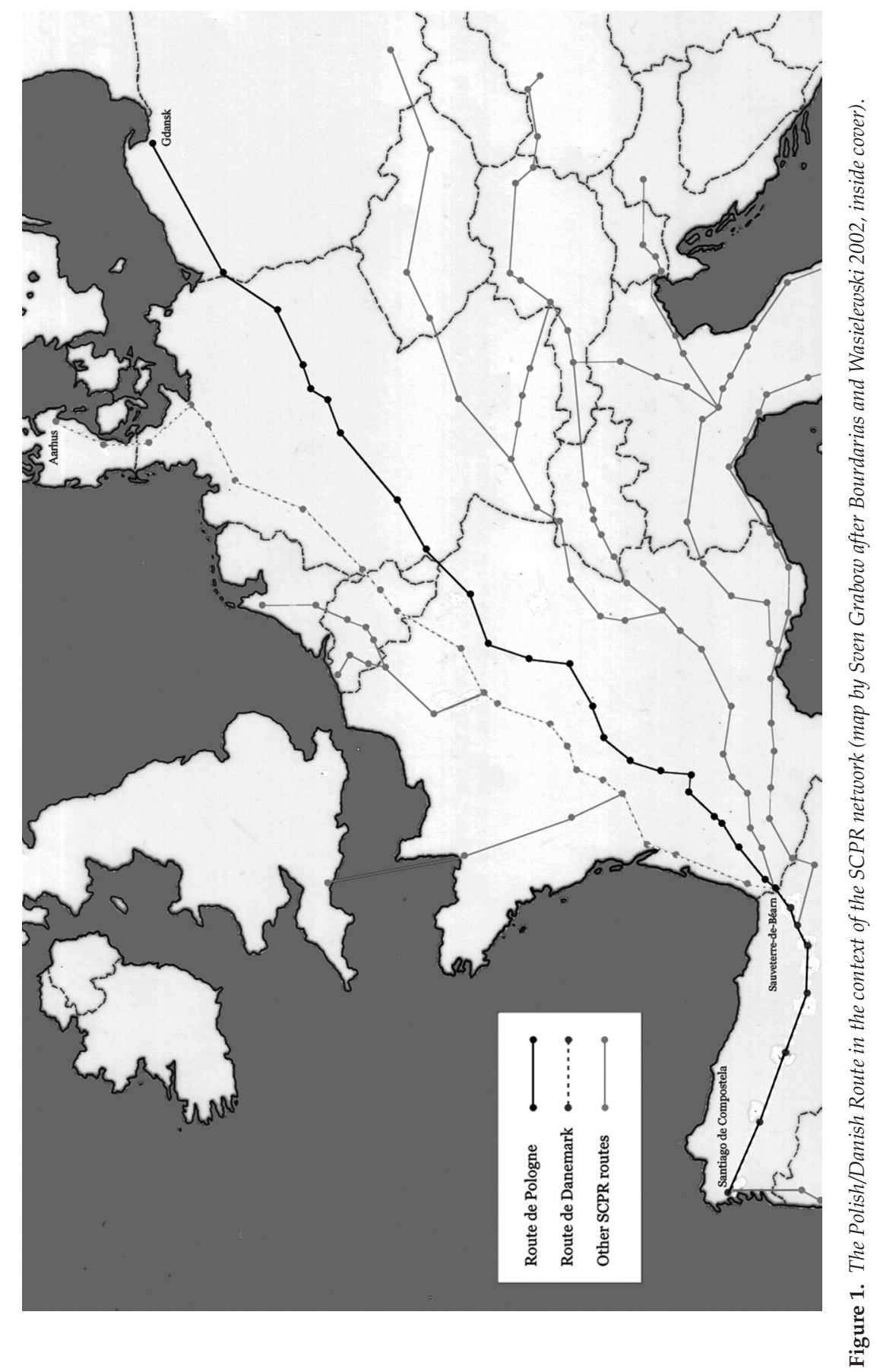




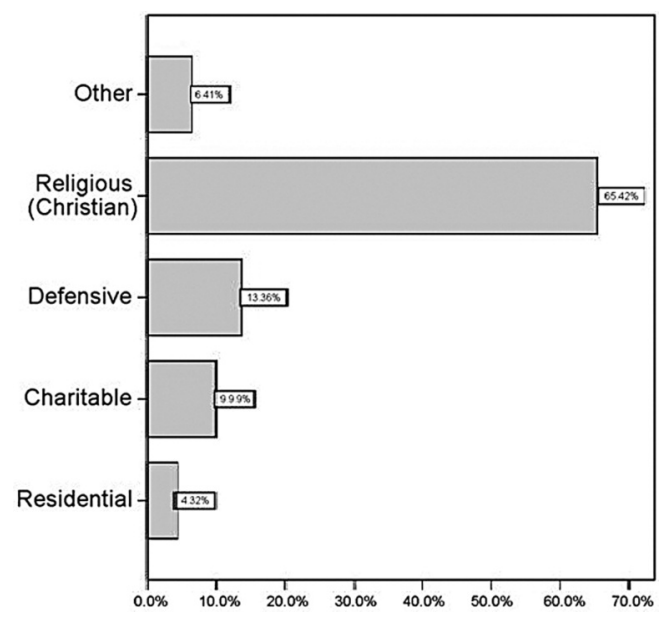

Figure 2. The Polish/Danish Route: proportional comparison of the categories of cultural heritage sites identified in the present study.

alternative sub-routes available. ${ }^{5}$ As such, the Polish/Danish Route, as devised by the $\mathrm{CoE}$ and its EICR, represents a closed body of cultural heritage grammar reaching from one of the SCPR network's easternmost points all the way to SdC at the western end of the Eurasian continent. It thus provides the full width of cultural heritage sites as would be encountered by a cultural tourist travelling the SCPR on a linear route from Gdansk to SdC.

For the purpose of the present study, each cultural heritage site on the Polish/Danish Route was entered into a SPSS 12.0.1 database $(n=673)$. As such the analysis has recourse to the entirety of architectural cultural heritage elements officially included in the Polish/Danish Route. Data were collected in terms of a number of variables, which will be discussed in detail in the following. In order to sketch the overall discursive and ideological thrust as expressed through the cultural heritage site grammar employed in the Polish/Danish Route, each element, where appropriate, was allocated to a broader category based on the overall function of a site (Fig. 2). For example, all Christian religious sites, be they churches, monasteries, or roadside crosses, were combined under the theme 'Religious (Christian)'. Categories accounting for less than three per cent were collapsed into 'Other'.

\section{Christian religious cultural heritage sites}

After categorization, we find that heritage sites of a Christian religious nature heavily dominate the SCPR's thematic character (65.4\%). This might appear the result to be expected in the context of an ECR revolving around a Christian pilgrimage phenomenon. However, besides alternative choices always being possible, this position of dominance can only be justifiable for Christian religious sites demonstrated to have some direct connection to St James and/or the pilgrimage to SdC. After all, the SCPR claim to be based on the pilgrimage phenomenon to SdC 


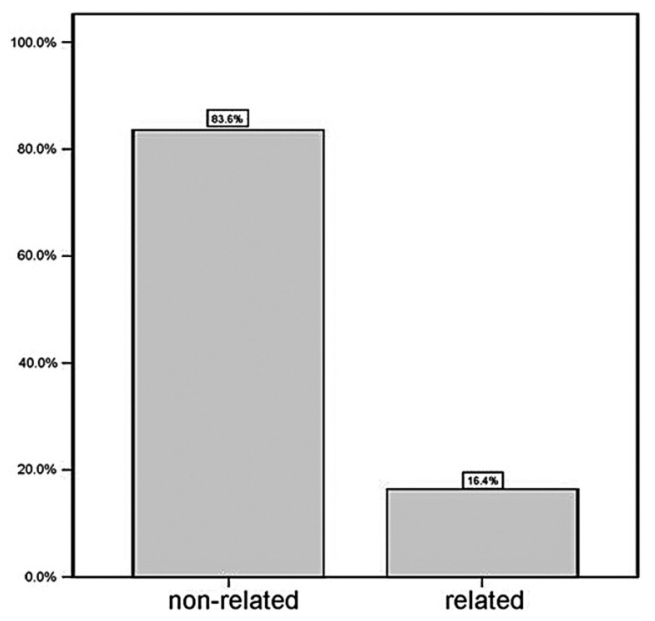

Figure 3. The Polish/Danish Route: proportional comparison of Christian religious heritage sites which are related or non-related to St James

and not on the theme of the Christian religion as a whole. However, of all Christian religious sites included, it is only in 16.4 per cent $(n=439)$ of cases that the CoE's official SCPR guidebook ${ }^{6}$ (Bourdarias and Wasielewski 2002) - listing each SCPR heritage site as part of its particular route, and providing information, whenever possible, on a site's connection to St James and the pilgrimage to SdC - can demonstrate a direct connection (Fig. 3).

As Figure 4 demonstrates, when grouped according to the modern-day country in which a site can be found, the number of religious sites related to the SCPR's overall theme (i.e. the medieval pilgrimage phenomenon to SdC) drops dramatically the further away they are from SdC. Only in the case of Spain can at least half $(56.2 \%)$ of the Christian religious cultural heritage sites included in the Polish/Danish Route be thematically related. In the case of France, this number already drops to only slightly more than a third (37.0\%), whilst for Germany only 5.4 per cent of the sites are thematically connected. In the case of Poland, the easternmost starting point of the route, a mere 1.4 per cent is demonstrated to be thematically linked. This distribution recalls Alsina's (1989:50) assessment that specific pilgrim routes to SdC and associated sites are extremely difficult to identify outside of Spain and France. In fact, even in those cases where a connection can be demonstrated by the CoE-edited and CoE-endorsed SCPR guidebook, the thematic link is often far-fetched as, for example, the single stained-glass window portraying St James in the church of Baugy (France), a church exhibiting numerous other windows dedicated to a variety of Christian saints (Bourdarias and Wasielewski 2002:214). As such it has no more connection to St James than to many other saints. 


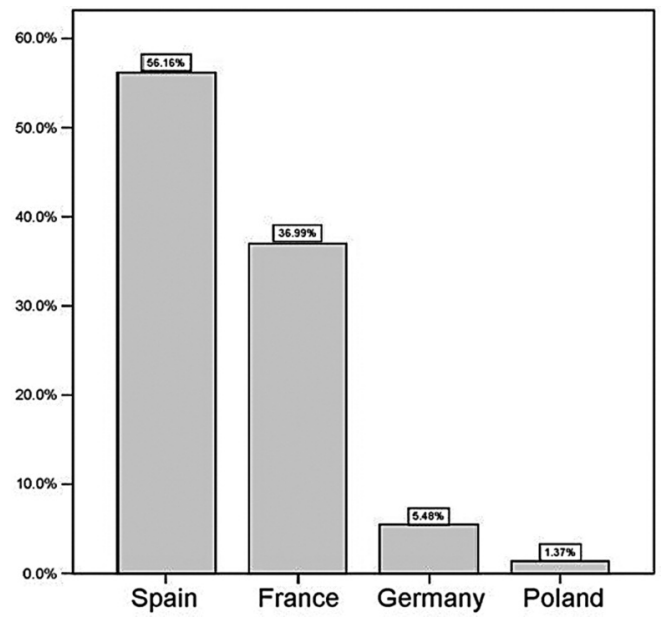

Figure 4. The Polish/Danish Route: proportional comparison by country of Christian religious heritage sites related to St James

In other cases the connection is merely the existence of a statue of St James among those of other Apostles and saints inside a church not dedicated or otherwise directly related to the saint or the pilgrimage to $\mathrm{SdC}$, such as in the case of the church of St Elisabeth at Marburg in Germany (Bourdarias and Wasielewski 2002:187), or a single sculptural detail, such as the small scallop shell ornaments ${ }^{7}$ to be found on the façade of St Jean-d'Estissac, Villamblart in France (Bourdarias and Wasielewski 2002:245). In another case an otherwise SCPR-unrelated village and its church are included on the basis of Pope John Paul II having visited it in 1987 (Bourdarias and Wasielewski 2002:174). Thus, it can be observed that the Polish/Danish Route's heritage site discourse revolves more around Christianity as a whole than around St James and the pilgrimage to SdC. The requirement of a direct link to the main theme is sacrificed in favour of an expansion of the route's network to as many European countries as possible, however removed from the recognized pilgrimage routes to SdC (see Fig. 1). In areas where directly related cultural heritage sites are largely missing, this evidential void is filled with general, thematically unrelated Christian religious sites.

Also an element of the SCPR's ideological discourse, this focus is further emphasized in the official guidebook's thematic organization. Any information provided for each town included on the route consists of two categories. The first category is entitled The History, the second The Town and its Churches. ${ }^{8}$ As such, while claiming the SCPR to represent a cultural tourism approach based on 'the idea of culture experienced in dialogue between identities' (CoE 16.06.1994:8) that can 'be interpreted in very different ways' (CoE 19.11.1993:2), the information given on churches, the majority of which is unrelated to the route's theme, heavily 
outweighs that given on the city, town, or village, or, in fact, on any other type of cultural heritage site.

In addition to what could be termed a theme-independent discourse of Christian veneration, the Polish/Danish Route's cultural heritage site grammar can further be argued to be evangelical in character. In terms of ritual function, it is in particular the mostly medieval ornate fonts to be found in some of the churches and cathedrals included, often emphasized by a photograph, ${ }^{9}$ to which the cultural tourist's attention is directed by the CoE's official SCPR guidebook. For example, in the context of the church of St Basileus, Münden (Germany), the guidebook states that '[1]a pièce la plus intéressante est constituée par les fonts baptismaux en bronze de 1392' (Bourdarias and Wasielewski 2002:186). Nevertheless, the guidebook fails to provide any information that would link this heritage site, or its fonts, with St James or the pilgrimage to SdC. Other examples include: the fonts inside the church of Viloria de la Rioja (Spain); those inside the church of Osorno (Spain); the font of St Stephanus, Halberstadt (Germany); those inside the church of Santa Maria in Münden (Germany); and the fonts at St Kastor, Kobern-Gondorf, also in Germany (Bourdarias and Wasielewski 2002:143, 148, 180, 186, 191). Preferentially directing the cultural tourist's attention towards the baptisteries of churches and cathedrals, such as in the case of St Étienne, Châlons-en-Champagne and Saint-Cyr-Sainte-Juliette, Nièvre, both in France (Bourdarias and Wasielewski 2002:201, 224), arguably further intensifies this discursive phenomenon. Further strengthening this discursive character, the Polish/Danish Route places particular emphasis on the figure of St John the Baptist, whether in the shape of statues, reliquaries, or murals depicting his life and deeds (see Bourdarias and Wasielewski 2002:183, 185, 205, 224 for just a small selection).

In summary, therefore, it can be argued that the Polish/Danish Route guides the cultural tourist, quite literally, from baptism to baptism - an act that could hardly be more ideological. Instead of telling, at least primarily, the story of St James and the medieval pilgrimage phenomenon to SdC, the SCPR's ideological thrust is directed towards Christianity in general and that of conversion in particular.

It is in the context of Christianity and conversion that the very few pre-Christian cultural heritage sites included in the Polish/Danish Route $(0.7 \%)$ - and which have as much to do with St James and the pilgrimage to SdC as many of the Christian religious sites included - are met with near commentary silence in the CoE's official SCPR guidebook. However, in the very few cases when they are provided with a contextual commentary, pre-Christian cultural heritage sites are presented as the material remains of crude and barbaric cultures having long disappeared owing to the success of a 'superior' Christian faith. For example, the guidebook states the dolmens at Saint-Priest-la-Feuille and Rebeyrole (France) represent a 'signe trés ancien de cultures primitifs' (Bourdarias and Wasielewski 2002: 232). In a similar vein, the Viking runestone at Jelling (Denmark) qualifies for inclusion in the context of the SCPR only in so far as it is used to represent 'le symbole du passage du people danois du paganisme au Christianisme, du culte des ancêstres a celui rendu au Christ' (Bourdarias and Wasielewski 2002:59). As such it can be argued that pre-Christian heritage is largely only incorporated in the SCPR 
in order to testify to the European development from the 'primitive' and 'dark' times of paganism to a 'civilized' and 'enlightened' Christian Europe. The pagan past is smiled upon from a position of spiritual maturity, whilst Christianity is presented as Europe's unifying force.

\section{'Defensive' cultural heritage sites}

Returning to the thematic categories already identified for the corpus of cultural heritage sites forming the Polish/Danish Route, the second most prominent group $(13.9 \%)$ consists of structures of a mainly defensive, protective and largely military character (see Fig. 2). These comprise castles, fortresses and, in the majority of cases, village and town fortifications. Castles, bastions, and fortresses incorporated in the route, to name but two, include the remains of the fortress at Pierre-Perthuis and the Count of Never's well-defended castle at Bazoches, both in France (Bourdarias and Wasielewski 2002:221, 222). In the case of town fortifications it is in particular the towering, access-controlling and often visually intimidating gates that are given primary emphasis. Examples include the Roman Porta Nigra, Trier (Germany) and the fourteenth-century Porte Chaussée, at Verdun in France (Bourdarias and Wasielewski 2002:193, 197). However, as Figure 5 highlights, in similar fashion to the Christian religious sites discussed in the last section, the vast majority (90.4\%; n=94) of 'defensive' sites included in the Polish/Danish Route cannot be demonstrated to have any direct connection or relevance to the theme of St James and/or the pilgrimage to SdC. As such, the inclusion of cultural heritage sites of a defensive-protective character must be considered more ideologically than thematically driven.

The defensive-military and protective character of this cultural heritage theme is given further weight, and directly linked with the theme of Christianity, by the many medieval commanderies - bases of operations for medieval Christian monastic orders of knights (e.g. Knights Templars and Teutonic Knights) included in the Polish/Danish Route (e.g. Bourdarias and Wasielewski 2002:137, $172,185,234,250)$. At the same time, cultural heritage site-related references to various military Christian monastic orders and their most prominent members feature heavily throughout the CoE's official SCPR guidebook (e.g. Bourdarias and Wasielewski 2002:138, 161, 187, 207).

Symbolically speaking, in the context of this particular mode of constructing pan-European heritage, the defensive cultural heritage sites included protect from the hostile outside an inside that is filled with exclusivist notions of the Christian faith. Christianity, it can be argued, is discursively constructed as something that has to be defended and protected from outside influences, if necessary by force.

With the Christian religion in general filling out most of the qualified cultural heritage paradigm as generated by the Polish/Danish Route, who or what is symbolically being denied access? And from whom is this Europe defined by Christianity being protected? The Polish/Danish Route, as well as the SCPR in general, holds material and symbolic clues to the answer of this question. On numerous occasions, cultural heritage sites qualify for inclusion in the SCPR not on 


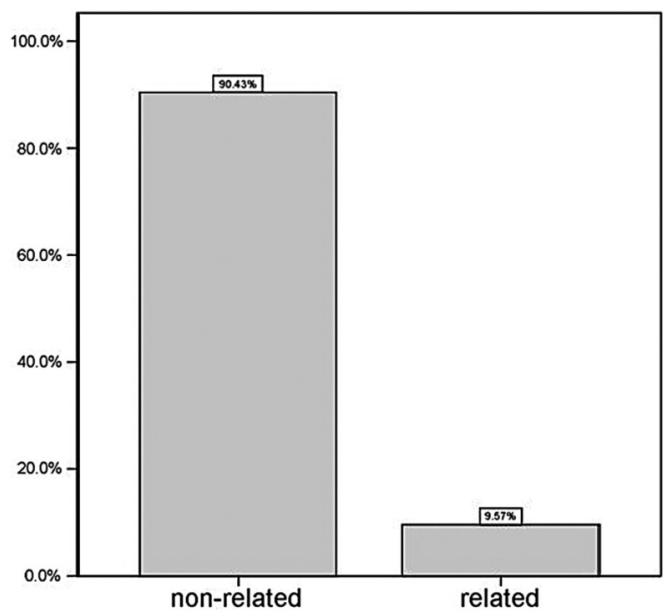

Figure 5. The Polish/Danish Route: proportional comparison of 'Defensive' cultural heritage sites which are related or non-related to St James

the grounds of a thematic connection to St James or the pilgrimage to SdC, but by their ability to present Muslim civilization in a negative and barbaric light. It is Muslim civilization that is discursively denied access to this particular mode of constructing pan-European heritage. For example, the small priory church of Espalion (France) only qualifies for inclusion as part of the SCPR in that it 'a été édifié à l'endroit où Hilarion fut décapité par les Sarrasins sous le règne de Charlemagne' (Bourdarias and Wasielewski 2002:321), while the abbey of Moissac (France) is highlighted as having been '[d]évastée par les Arabes en 734-736' (Bourdarias and Wasielewski 2002:332). Similarly, the small Spanish town of Logroño is lamented for having suffered in fights against Arabs (Bourdarias and Wasielewski 2002:140) and the cathedral of Villafrance Montes de Oca (Spain) because it 'fut ruinée par les Arabes lorsqu'ils assiégèrent la ville' (Bourdarias and Wasielewski 2002:144), whilst the small town of Sisteron (France) is introduced to the traveller as a village that 'fut pillée par les Sarrasins et ne retrouva sa prospérité qu'au XIe siècle' (Bourdarias and Wasielewski 2002:426). To present one last example, in reference to the abbey of Cannes (France), the SCPR guidebook explains that 'les invasions sarrasines, l'assassinat de l'abbé et des 50 moines, provoquèrent le déclin du monastère' (Bourdarias and Wasielewski 2002:488).

In a similar fashion, cultural heritage sites thematically unrelated to St James are included in the Polish/Danish Route on the basis that they provide references to Christian military victories over Muslims, such as in the case of the small church of Santa Maria del Camino o de la Victoria (Spain), included only in reference to the sculptural detail of bulls carved on its façade alluding to the local 'victoire remportée sur les Maures par un troupeau des taureux furieux' (Bourdarias and Wasielewski 2002:149, see also 212, 329, 495, 501). 
In terms of historical figures it is, for example, Roland of Ronceveaux (Bourdarias and Wasielewski 2002:122, 125, 135-136), nephew of Charlemagne, and commander of the rearguard of his forces, who qualifies for inclusion in the CoE-edited official SCPR guidebook in the context of his last stand against a superior Arab force. Similarly, Charles 'The Moor Hammer' Mantel, lacking any direct connection to the route's theme, is selected for inclusion on the grounds that he 'défit les Arabes' at Poitiers (Bourdarias and Wasielewski 2002:112), with the result that, '[a]près de multiples incursions, les musulmans seront repoussés en 721' (Bourdarias and Wasielewski 2002:439). It is in the same discursive context that Ramiro I is included as the Christian noble who defeated Muslim forces near the village of Clavijo (Spain) in May AD 844 (Bourdarias and Wasielewski 2002:141). As mentioned earlier, many historians doubt the battle to have ever occurred, instead arguing that it was invented as part of anti-Islamic medieval propaganda (see Gitlitz and Davidson 2000:xiv). In the guidebook, however, the battle is presented as historical fact: 'C'est ici que s'est déroulée la bataille entre Ramiro Ier des Asturies et le chef arabe Abderraman II en mai 844' (Bourdarias and Wasielewski 2002:141). Nevertheless, it is this doubtful battle that qualifies Clavijo - a settlement possessing no direct link to the pilgrimage to SdC, and a link to St James only in a military context - to be included in the Polish/Danish Route. What all these historical figures have in common is that they are either presented, as in the case of Charlemagne, as protectors of a Christian Europe (Bourdarias and Wasielewski 2002:74) or, as in the case of the Roman Emperor Constantine, 'vainqueur[s] du paganisme' (Bourdarias and Wasielewski 2002:115).

Taking all this together, in an act of evaluative delimination, ${ }^{10}$ Muslims are continuously presented in the context of barbarism, aggression, invasion and destruction - a threat to Europe and European culture (in this context, see Asad 2002:227; Kabbani 2001:1; Said 1978:12-13). Doing so, the SCPR can be argued to form part of a wider western Orientalist ideology in which, in the words of Haddad (1999:631), Islam, as well as Muslim culture in general, is construed as:

a religion that is devoid of integrity and progressive values, a religion that promotes violent passions in its adherents, a menace to civil society, and a threat to the peace-loving people of the world. Muslims are often cast as bloodthirsty, whose loyalty as citizens must be questioned because they are perceived to be obsessed with the destruction of the West.

Seeking a pan-European cultural identity model, the SCPR develop the notion of a Christian European Self at the expense of the notion of a Muslim nonEuropean Other. ${ }^{11}$

\section{'Charitable' cultural heritage sites}

The third most prominent group amongst the thematic categories of cultural heritage sites making up the Polish/Danish Route (yet only accounting for 10.0\% of the total), consists of cultural heritage sites primarily 'charitable' in character 


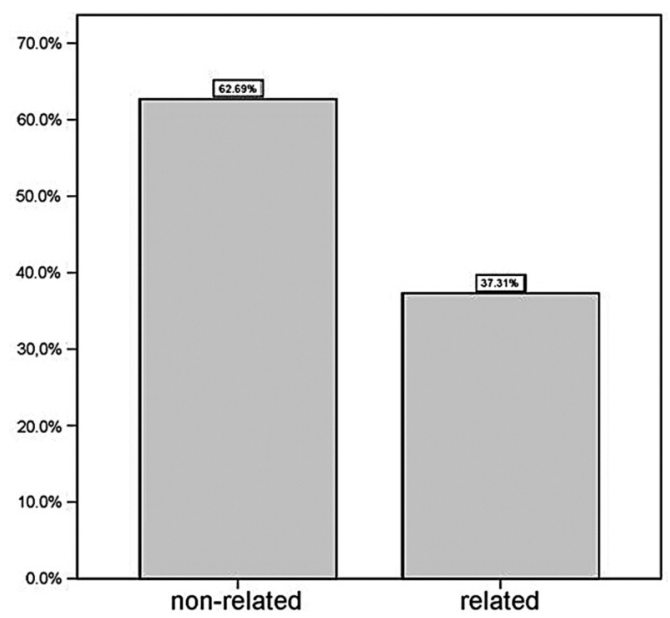

Figure 6. The Polish/Danish Route: proportional comparison of 'Charitable' cultural heritage sites related and non-related to St James.

(see Fig. 2). To clarify, this category mainly includes medieval hospitals and hospices caring for the sick, such as the tenth-century AD hospital of Irache (Spain) and the ruins of the pilgrim hospital of Bassaou in France (Bourdarias and Wasielewski 2002:139, 253). With 37.3 per cent $(n=67)$, more than twice the number of these sites when compared to Christian religious sites and three times the number when compared to 'defensive' sites can be linked to St James and/or the pilgrimage to SdC (Fig. 6). As such, of all heritage site categories analysed to this point, it is the hospitals and hospices that are comparatively most justified in their inclusion in the SCPR in terms of their demonstrated thematic connection. Nevertheless, only every tenth site falls into this category. Also, unlike sites belonging to the other categories identified so far, no particular attention is drawn to them in terms of photographs included in the SCPR guidebook. In fact, only two photographic representations of a 'charitable' cultural heritage site are to be found amongst the more than 427 photographs of cultural heritage sites included (see Bourdarias and Wasielewski 2002:120, 517).

It can be argued, therefore, that the hospitals and hospices included in the SCPR, although in their thematic connection to St James and the pilgrimage to SdC being the most justified for inclusion, are given only minimal discursive weight. 'Charitable' cultural heritage sites, whilst included, are being marginalized.

\section{'Residential' cultural heritage sites}

A very different pattern to the foregoing can be observed for the last major category of heritage sites discussed here. As shown in Figure 2, heritage sites of a 'residential' character make up 4.3 per cent of the cultural heritage sites on the Polish/Danish Route. This category consists of the mainly representational residences (i.e. palaces, stately homes and so on) of Europe's secular élite. These 
include, for example, the seat of the Dukes of Pomerania at Darlowo (Poland) and the palace of the Dukes of Nevers at Metz-le-Comte in France (Bourdarias and Wasielewski 2002:173, 208). However, unlike 'charitable' sites, even though the entirety of 'residential' heritage sites included in the Polish/Danish Route $(n=29)$ cannot be demonstrated to have any direct connection to St James and/or the pilgrimage to $\mathrm{SdC}$, it is 24.1 per cent of all 'residential' sites that are emphasized in the guidebook by a photograph. Even though utterly unrelated to the cultural route's theme, representational residences are discursively emphasized.

\section{Info-Boxes on Historical Figures}

Having discussed the SCPR's ideology in terms of cultural heritage sites on the ground, as well as in terms of the additional emphasis placed on certain sites in terms of accompanying photographs, one last important discursive element to be found in the officially endorsed guidebook can be discussed. Besides cultural heritage sites and related information, the official SCPR guidebook includes a total of 204 info-boxes on historical figures deemed qualified for inclusion. Together with the other elements, they set the ideological context in which the cultural traveller experiences the SCPR.

In the large majority of cases $(89.2 \%)$, these boxes contain information on the lives and deaths of Christian saints (Fig. 7). Categories accounting for less than 1 per cent were collapsed into 'Other'. When including in this group Christian nobles who were granted sainthood, this number rises to 92.1 per cent. In fact, on its 559 pages, the SCPR guidebook contains a total of 182 of info-boxes on Christian saints (187 when including the category of Christian noble/saint), an average of one for every three pages. This number does not take into account the hundreds more saints mentioned or briefly discussed in the guidebook's accompanying text. Also, by providing the saint's day for each saint included in an info-box, the guidebook can be argued to become a hagiolatric 'timetable', a calendar for the veneration of Christianity and its figures. In terms of the concrete context in which Christian saints and nobles/saints are recognized as qualifying for inclusion in the SCPR guidebook info-boxes, the largest group (23.3\%) acquires recognition in reference to their conversion of non-Christians (Fig. 8). Entirely unrelated to St James and/or the pilgrimage to SdC, these include, for example, St Otto, St Boniface, and St Savinien (Bourdarias and Wasielewski 2002:176, 177, 202). Closely related to this category, and further strengthening its ideological thrust, 16.9 per cent of cases focus on Christian saints recognized by the Church for acts of martyrdom, in many cases in the context of conversion activity. These include St Castor, St Léger, and St Pèlerin (Bourdarias and Wasielewski 2002:191, 198, 208).

Similarly, the most prominent category of historical figures who were not saints, also unrelated to the SCPR's theme, is that of Christian personalities recognized by the church for their missionary activities, such as Pauline Jeuris, a Franciscan missionary killed in 1900 during the Boxer Revolt, Jacques Marquette, a seventeenthcentury missionary bringing the Christian faith to indigenous Canadians, and Toribio (AD 1538-1606), archbishop of Lima, who, after serving as the head of the Inquisition in Granada, was sent by Phillip II of Spain to spread the Christian faith 


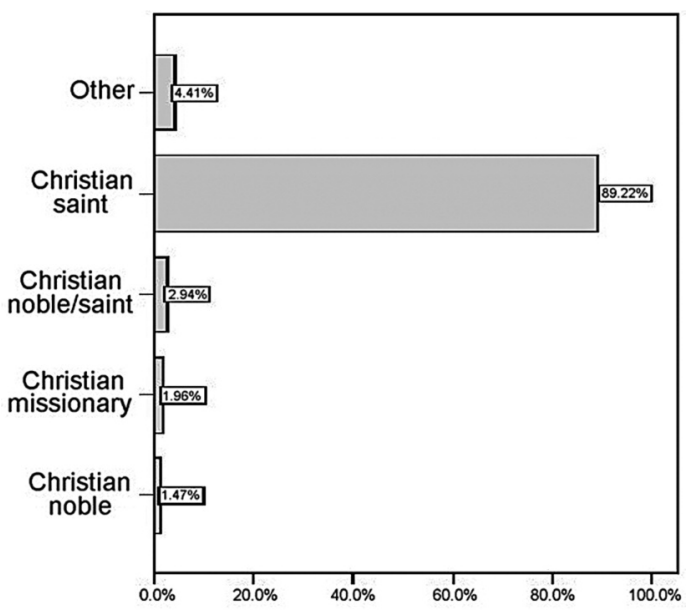

Figure 7. The Polish/Danish Route: proportional comparison of types of historical figures included in the SCPR guidebook's info-boxes.

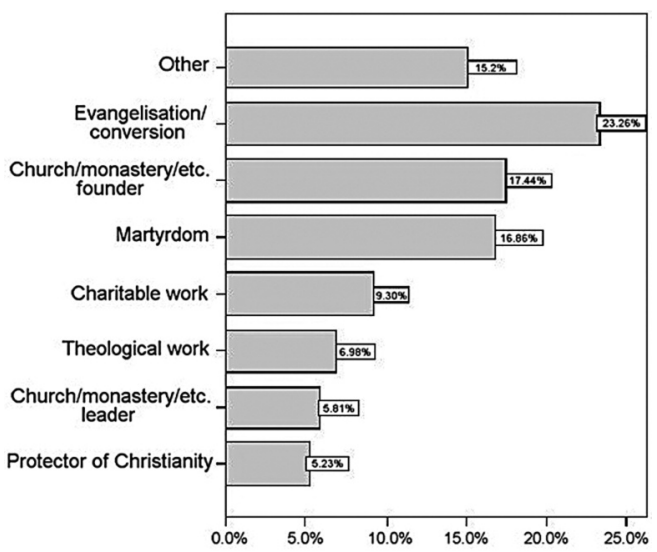

Figure 8. The Polish/Danish Route: proportional comparison of the context of recognition categories for Christian saints/nobles included in the SCPR guidebook's info-boxes.

in Peru (Bourdarias and Wasielewski 2002:76, 83, 153). With 17.4 per cent the second most prominent group, Christian saints are included in reference to the foundation of churches, monasteries, or other religious institutions. After the conversion of non-Christians, these figures established an ecclesiastical infrastructure. However, of all the historical figures included in the info-boxes, only 6.4 per cent are demonstrated to have even a distant connection to St James and/or the pilgrimage to SdC.

Taking all this together, it can be argued that the SCPR guidebook's use of historical figures in these special info-boxes further intensifies the project's discourse 
of 'conversion', as identified previously for its cultural heritage site selection. The counter-argument might be that the inclusion of Christian saints and other Christian figures in a guidebook about cultural heritage sites linked through a Christian theme represents a natural state of affairs. However, in particular with reference to Billig's (1995) notion of banal nationalism, there exists no so-called 'natural state of affairs' when it comes to practices of identity construction. Even if an identity/ideology paradigm (i.e. a particular understanding of the world) appears 'to possess a reassuring normality' (Billig 1995:7), this perceived normality is itself subject-dependent and does by no means translate into objective neutrality. In fact, it is precisely this reassuring normality that turns it into a powerful measure of influencing notions of identity.

\section{THE SCPR: A PAN-EUROPEAN IDENTITY PARAdIGM}

The ideology identified in the foregoing critical study may not be representative of the opinions and ideas of every individual Eurocrat. How could it? Yet, as a subject for a case study, the SCPR represent one of the most important implemented crystallizations of a pan-European cultural heritage paradigm, and, as such, must be assessed against their generating body's claims to multiculturalism, pluralism, multivocality and, in particular, religious open-mindedness. Having critically examined the Polish/Danish Route's context, content and character of mediation, the results of this analysis are summarized in graphic form in Figure 9. Here it should be mentioned that, because of space restrictions, this article was able to discuss only a limited number of all SCPR cultural heritage sites, in other words those included on the Polish/Danish Route. However, a detailed study of the SCPR in its entirety matches the analytical results of the Polish/Danish Route (Grabow 2006).

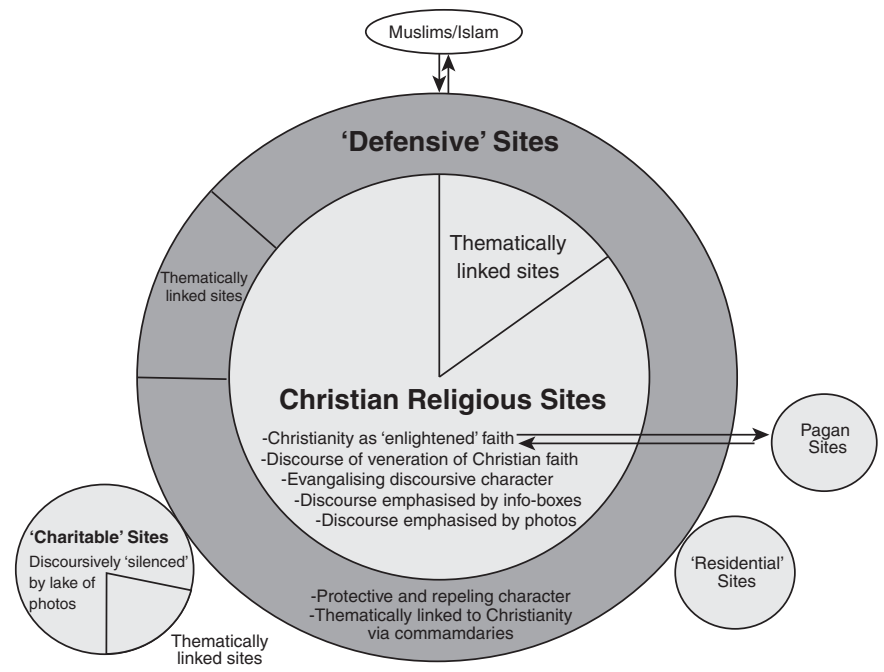

Figure 9. The Polish/Danish Route: the SCPR's 'ideoscape'. 
As the assessment given here of the Polish/Danish Route's cultural heritage grammar demonstrated, although a thematic connection can be demonstrated for at least half of all Spanish sites, pilgrimage routes identified for France and, in particular, for Germany and Poland, must be considered largely unsupported by archaeological/historical evidence. In order to inflate the geographical 'spread' of the SCPR network, evidence is 'sacrificed' in favour of a panEuropean ideal, which is the concept of pilgrimage routes to SdC having densely criss-crossed the 'continent'. Further, the SCPR, having been portrayed by the $\mathrm{CoE}$ as representing the most 'European' of all ECRs (e.g. CoE 25.05.1988:8; see also Thomas-Penette 2003:187), have been demonstrated in their discursive character to be characterized less by the theme of St James and the pilgrimage to $\mathrm{SdC}$, than by the wider theme of a defensive Europe exclusively united in Christianity. Whilst generating a discourse around the veneration of, and conversion to, the Christian faith (such as through its emphasis on fonts and baptisteries, the use of pagan sites, and the inclusion of hundreds of info-boxes in the SCPR guidebook containing information on the lives mainly of Christian saints and others preaching the Christian faith) the threat, against which it has to be defended (as generated by the inclusion of 'defensive', themeunrelated cultural heritage sites), takes the form of Muslims and Islam. Both are continuously presented in a negative way as equating with barbarism, aggression, and violence. Thus it can be argued that in the case of the SCPR, stated by the CoE (01.10.1996:6) to 'symbolise first and foremost the process of European construction', the process of pan-European identity construction (Self) takes the shape of a Europe united in Christianity in opposition to Muslim civilization (Other). Instead of developing an open and organic identity model, the SCPR develop an inward-looking identity paradigm in which a European in-group is defined and united in opposition to an allegedly non-European out-group, a distinction based on faith. In this context it is difficult not to recall the notion of the 'Fortress Europe'12 (see Heintz 2001; Kubicek 2003).

Instead of encouraging cultural tolerance and diversity and combating cultural isolation, the SCPR develop a pan-European cultural heritage paradigm characterized by closed-ness, exclusivity, and homogeneity. In doing so, the SCPR create an idea of pan-European cultural identity based on the alienation and exclusion of a large majority of Europe's population. This is particularly the case for the 20 million or so Muslims living in Europe today, but it also holds true for the millions of Hindus, Sikhs and Jews. Further, an inward-looking paradigm is ill-suited to counteract the trend towards the reinforcement of national identities observable across many of Europe's nation-states. The SCPR are unlikely to have a positive impact on the growing problem of nation-based religiously, ethnically, or racially motivated violence spreading across Europe. Also, with Europe's borders being, because of their discursive nature, organic and in a continuous state of flux, present-day and future Europeans are likely to feel alienated by a hard and fast identity framework based on a single cultural aspect (religion) and on only one of its facets (western Christianity). It is in this context that the CoE's decision to develop a flagship model for cultural cooperation based on a symbol of medieval politico-religious propaganda revolving 
around the supposedly rightful struggle of European Christians against European Muslims must be questioned. Instead of working towards the development of a new common heritage model, a medieval common identity model that by its very nature - even though aiming to unite Europeans - stands against notions of openness, inclusivity and religious neutrality is revived. Turning back to the cultural past in order to mine it as a resource for the present is a promising and potentially powerful move. Yet, when doing so, more critical thought and care are needed. In conclusion, the SCPR, even though representing the ECRP's flagship project, must be considered ill-suited to facilitate the development of a pan-European identity paradigm based on the notion of cultural openness, pluralism, and multi-vocality. In this, the CoE and EICR fall short of their own policies. However, the SCPR's failure to do so does not mean that the ECRP has done so as a whole.

\section{THE SCPR AND ECRP: Historic SPECIFICITY AND RECENT DEVELOPMENTS}

Assessing the SCPR in terms of the current context of its corpus of ECRs, it must first be pointed out that, as mentioned previously, it represents the first ever developed. Implemented 21 years ago, CoE culture policy, and with it the ECRP, has been developing ever since (see CoE 2007 for its most recent paper on ECRs). As a result of this development, and, in particular, a renewed emphasis, which aims to encourage 'intercultural dialogue and ... [to] facilitate conflict prevention and reconciliation' (CoE 2007:1), as well as an emphasis on the 'co-operation between Europe and other continents through the special affinities between certain regions' (CoE 2007:4), recent decades have seen the ECRP being extended by numerous ECRs that can be argued to successfully communicate the idea of a multi-cultural pan-European identity paradigm that develops its meaning in exchange with the wider world.

Perhaps of foremost importance in the context of anti-Islamic sentiments as identified for the SCPR is the CoE's Legacy of Al-Andalus route. Inaugurated in 1997 and revolving around the historical, social, and cultural relations of the Muslim medieval Iberian kingdom of Al-Andalus with the Christian, Arab, and the Mediterranean world in general, this ECR aims 'to make known the hispanoMoslem civilization, its artistic events, as well as the historical and social bonds between Europe and the Arab world' (EICR 2004b) and to 'spread the historical role that Spain and Andalusia played as a cultural bridge between the Orient and Occident' (EICR 2004b).

Instead of looking inwards in search of a pan-European identity, the CoE and EICR are developing an outward looking paradigm highlighting modern Europe as being the result of multi-cultural influences, including non-Christian faiths. Further advances in this direction have taken the form of the European Jewish Heritage Route, integrated into the ECRP in 2004. Here, in order to further interculturality, by recreating 'a cross-cultural, pan-European space in which European citizens can discover the variety and value of Jewish heritage throughout the European continent' (EICR 2006), Jewish culture is discursively constructed as 'an integral part of European history and culture' (EICR 2006).

Avoiding an inward-looking definition of Europe, other more recently developed ECRs place Europe in its wider cultural context, particularly in relation to 
northern Africa and the Near East. It is in this context that the Phoenician ECR designated in 1994 aims to draw the attention of Europeans to the cultural and economic role the Mediterranean - both sides of it - has played for millennia, with '[t]he Phoenicians, originating in current Lebanon, [having] largely contributed to the economic and civilising importance of this sea' (EICR 2008a). Its routes, so far, cover Greece, Italy, Spain, and Tunisia. Displaying a similar 'outgoing' character, the Routes of the Olive Tree, first established 1999, focuses on the natural heritage of the olive tree and 'the technical, social and cultural development of the civilisations inhabiting the Mediterranean basin since ancient times' (EICR 2008b). Undergoing a major period of expansion between 1999 and 2004, the route at present includes every country with access to the Mediterranean, from Spain in the west to Syria in the east, and from France in the North to Libya in the South.

In summary, during the two decades following the implementation of the SCPR, the ECRP's first cultural route, the project's content has actively turned towards the inclusion and mediation of non-Christian faiths and cultures in terms of their importance for European culture. Further, instead of continuing to display Europe as a closed and tightly guarded cultural space ('Fortress Europe'), new ECRs have started to look outwards and to flag up its organic and discursive nature. In doing so, instead of a hard and fast whole, a pan-European cultural identity paradigm is generated that acquires its meaning through its relationship and contacts with the wider world.

\section{CONCLUSION}

As this analysis has demonstrated, the SCPR's ideological discourse fails to meet the project's aims of multiculturalism and, in particular, religious open-mindedness. However, with the ECRP having diversified in terms of its themes during the last two decades, and, in particular, having left behind a strictly inward-looking idea of Europe by devoting more of its ECRs to the notion of multi-culturalism and multi-faith, the SCPR should not be understood as an expression of the overall failure of the CoE to develop projects of culture in support of a multi-cultural pan-European identity concept. Instead it reflects how far the CoE and EICR have progressed since the coming into being of the first ECR. However, at the same time the ECRP's more recent developments have also highlighted the CoE/EICR's failure to redesign the SCPR, in particular in its role as the project's flagship, to adopt and reflect the changes that have occurred over the last two decades. As such, this article calls for a critical revision of the SCPR's content in terms of its qualified cultural heritage sites and their context/mode of mediation.

\section{ACKNOWLEDGEMENTS}

I would like to thank Michel Thomas-Penette (Director of the EICR) and Sorina Kapp (Administrative Manager of the EICR) for granting me access to the ECRP archives and databases. Thanks must also go to Jenny Walker for commenting on earlier drafts of this article. 


\section{Abbreviations}

$\begin{array}{ll}\text { CDA } & \text { Critical Discourse Analysis } \\ \text { CEC } & \text { Commission of the European Communities } \\ \text { CoE } & \text { Council of Europe } \\ \text { ECR(s) } & \text { European Cultural Route(s) } \\ \text { ECRP } & \text { European Cultural Routes Project } \\ \text { EICR } & \text { European Institute of Cultural Routes } \\ \text { EU } & \text { European Union } \\ \text { SCPR } & \text { Santiago de Compostela Pilgrim Routes } \\ \text { SdC } & \text { Santiago de Compostela } \\ \text { VCA } & \text { Visual Content Analysis }\end{array}$

\section{Notes}

1. Michel Thomas-Penette, the Director of the European Institute of Cultural Routes, was interviewed by the author in Luxembourg on 17 October 2003.

2. It must be mentioned that many historians doubt that this battle ever occurred (Gitlitz and Davidson 2000:xiv).

3. In fact, as early as the eleventh century Pope Calixtus II declared northern Spain a holy land and the wars against Iberian Muslims crusades (Fletcher 1984:297-298).

4. In the following article text, the term refers to the combination of routes as shown in Figure 1.

5. Exceptionally, between the French towns of Bénévent-l'Abbaye and Cahors, for a distance of $268 \mathrm{~km}$, there exist two alternative routes running parallel to each other (see Bourdarias and Wasielewski 2002:234-235). For the following analysis, the first of the two routes was chosen on the basis of a random selection.

6. Here it must be pointed out that the SCPR guidebook represents the sole source for the entirety of cultural heritage elements officially included in the SCPR, and is a necessity for anyone planning to travel to $\mathrm{SdC}$ following the CoE's take on the pilgrimage phenomenon. It was published under the CoE's full editorial control. As a result, its contents - from the heritage sites included to form the routes, via the accompanying text, to the photographs presented - represent the CoE's only endorsed interpretation of the medieval pilgrimage phenomenon to $\mathrm{SdC}$ as a pan-European identity model for the present.

7. The legend has it that when St James's followers dragged the boat holding the apostle's body onto the beach a horseman went by. When the horse bolted in fear from St James's relics, it lunged into the sea, taking the rider with it. Miraculously re-emerging unscathed from the deep waters, the horse and rider were covered in scallop shells (Luard 1998:79). It is because of this legend that the scallop shell has become a symbol for St James and the pilgrimage to SdC.

8. In general this applies to bigger towns and cities. In the case of small towns and villages the guidebook does not structure the information given.

9. Even though the photographs of cultural heritage sites included in the SCPR guidebook were taken by Michel Wasielewski, a professional photographer, the decision over which photographs to include was made by the CoE's editorial team. As such the photographs form part of the official SCPR ideological discourse as much as the actual heritage sites.

10. The notion of evaluative delimination refers to the generation of the image of an in-group by contrasting it with the image of an inferior or dangerous out-group (see Fuchs et al. 1995:165).

11. It should be pointed out that the notion of a Muslim non-European Other has no foundation in the 'Continent's' cultural past. During different periods of its history, large parts of what is most commonly considered Europe have, sometimes for as many as 800 years, been occupied by Muslim cultures, for example Spain, Portugal, Sicily and Greece. Muslim cultural influence was, however, not only limited to those areas under direct Muslim control, but was felt in the rest of medieval and later Europe (see, for example, Harvey 1990). 
12. The notion of 'fortress Europe' refers to the exclusionist establishment of strengthened EU external border controls and access regulations following the replacement of border controls between EU states after the agreements of Trevi in 1976 and Schengen in1986 and 1990 (see Kofman and Sales 1992).

\section{REFERENCES}

AlsinA, F.L., 1989. The development of the Camino de Santiago in Castile and Leon between 850 and 1050. The Santiago de Compostela Pilgrim Routes. Report of the Bamberg Congress. Architectural Heritage Reports and Studies, No. 16: 4854. Strasbourg: Council of Europe, Publications and Documents Division.

AsAD, T., 2002. Muslims and European identity: can Europe represent Islam? In A. Pagden (ed.), The Idea of Europe: From Antiquity to the European Union: 209-227. Cambridge: Cambridge University Press and Woodrow Wilson Centre.

BALlester, J.M., 2002. Saint Jacques et L'Europe. In J. Bourdarias and M. Wasielewski, Guide Européen des Chemins de Compostelle (nouvelle édition revue et augmentée): 11-12. Lamnay: Le Sarment.

BELLIER, I. and T.M. WILSON, 2000. Building, imagining and experiencing Europe: institutions and identities in the European Union. In I. Bellier and T.M. Wilson (eds), An Anthropology of the European Union: Building, Imagining and Experiencing the New Europe: 1-27. Oxford: Berg.

BILLIG, M., 1995. Banal Nationalism. London: SAGE.

BOURDARIAS, J. and M. WASIELEWSKI, 2002. Guide Européen des chemins de Compostelle (nouvelle édition revue et augmentée). Lamnay: Le Sarment.

BROERS, M., 1996. Europe Under Napoleon, 1799-1815. London: Arnold.

COUNCIL OF EUROPE, 1954. European Cultural Convention (ETS 18-Cultural Convention, 19 July 1954). URL (consulted 1 October 2004): http:www. bologna-bergen2005.no/Docs/02-CoE/541219Cultura 1_con_018.pdf

COUNCIL OF EUROPE, 25.05.1988. European Cultural Routes: Secretary General's Memorandum Prepared by the Directorate of Education, Culture and Sport. ICE (88) 9.

COUNCIL OF EUROPE, 20.01.1992. European Cultural Routes: First Meeting of the 'European Cultural Itineraries' Group - Thoughts on Council of Europe Action in this Field. ICE (92) 3.

Council OF Europe, 11.01.1993. Second Meeting of the Advisory Committee (Meeting Report prepared by the Directorate of Education, Culture and Sport) (CD-CULT). ICCE (93) 1.

Council of Europe 19.11.1993. Revitalisation of the Santiago Pilgrim Ways: Ethics and Deontology of a Cultural Route. ICCE (93) 8.

Council of EUROPE, 17.03.1994. Practical Guide to Cultural Routes of the Council of Europe (Advisory Committee for Cultural Routes of the Council of Europe 3rd meeting) (CULT-CR). ICCE (94) 8 rev.

Council of Europe, 24.03.1994. Cultural Routes of the Council of Europe - Third Meeting of the Advisory Committee: Meeting Report (CULT-CR). ICCE (94) 13.

COUNCIL OF EUROPE, 16.06.1994. Council of Europe Cultural Routes - Culture and Tourism: Making Culture and Tourism Complementary and Interactive. ICCE (94) 20.

Council of Europe, 01.10.1996. Cultural Routes of the Council of Europe. Seminar on Cultural Routes - Challenges of Citizenship and Sustainable Development: Introductive Report. ICCE (96) 10.

Council of Europe, 27.04.1997. Cultural Routes of the Council of Europe - 5th Advisory Committee Meeting: Draft Rules (CULT-CR). ICCE (97) 12. 
CouncIl Of Europe, 2003a. European Cultural Routes. URL (consulted 15 July 2003): http: / / www.coe.int / T / E / Cultura1\%5FCo\%2Co-operation / Heritage/European\%5FCultural\%5FRoutes/_Summary.asp\#TopOfPage

Council of Europe, 2003b. The Santiago de Compostela Pilgrim Routes. URL (consulted 15 July 2003): http://www.coe.int/T/E/Cultural_Co-operation/ Heritage/European_Cultural_Routes/The_Cultural_Routes/1Stjaques.asp\# TopOfPage

COUNCIL OF EUROPE, 2004a. European Identity Now and in the Future. URL (consulted 8 July 2004): http://www.coe.int/T/E/Com/Files/Themes/Iden tity/default.asp

COUnCIL OF Europe, 2004b. Culture and Heritage. URL (consulted 29 June 2004): http://www.coe.int/T/E/Com/About_Coe/Culture.asp

COUNCIL OF EuROPE, 2007. Resolution CM/Res(2007)12 on the Cultural Routes of the Council of Europe (Adopted by the Committee of Ministers on 10 October 2007 at the 1006th meeting of the Ministers' Deputies). URL (consulted 16 November 2009): http://www.transromanicaserver.de/data/mediadb/ cms_mime/\%7B3e6e6235-11f3-d631-5c94-4b2b72c22dfb\%7D.pdf

Delanty, G., 1995. Inventing Europe: Idea, Identity, Reality. London: Macmillan.

Dobson, L., 2004. We have the stars, let's add the moon: EU, Turkey and the constitutional values of free citizens (The Federal Trust for Education \& Research Online Paper). URL (consulted 26 September 2004): http://europa.eu.int/ futurum/analyse/contrib/acad/0006_c21_en.pdf

DoDD, P., 2002. The quest for European identity. In D. Leonard and M. Leonard (eds), The Pro-European Reader: 189-195. Houndmills, Basingstoke, Hampshire: Palgrave.

Elliot, G., 1992. Twentieth-Century Book of the Dead. Harmondsworth: Penguin.

European Institute of Cultural Routes, 2003. The Cultural Routes Programme of the Council of Europe. Information document provided at the conference 'Industrial Society and Heritage - A New Cultural Route of the Council of Europe? From the Grande Région towards Europe', Château de Bourglinster, Grand-Duchy of Luxembourg, 24-25 October 2003.

European Institute of Cultural Routes, 2004a. The Pilgrim Pathways: The Santiago de Compostela Pilgrim Pathways. URL (consulted 9 August 2004): http:/ / www.culture-routes.lu/php/fo_index.php?lng=en\&dest= bd_pa_det\&id=00000003

EuropeAn Institute of Cultural Routes, 2004b. The Legacy of Al-Andalus: Arabs in Spain. URL (consulted 2 January 2004): http://www.culture-routes.lu/ php/fo_index.php?lng=en\&dest=bd_pa_det\&rub=59

European Institute of Cultural Routes, 2005. The Council of Europe Cultural Routes, Information Leaflet.

European Institute of Cultural Routes, 2006. European Jewish Heritage Route. URL (consulted 28 June 2006): http:/ / www.culture-routes.lu/php/fo_index. php?lng=en\&dest=bd_pa_det\&rub=73

European Institute of Cultural Routes, 2008a. The Phoenician Routes. URL (consulted 20 October 2008): http:/ /www.culture-routes.lu/php/fo_index.php? lng $=$ en\&dest $=$ bd_pa_det\&rub $=54$

European Institute of Cultural Routes, 2008b. The Routes of the Olive Tree. URL (consulted 20 October 2008): http://www.culture-routes.lu/php/fo_index. php?lng=en\&dest=bd_pa_det\&rub=77

Fletcher, R., 1984. St. James's Catapult: The Life and Times of Diego Gelmirez of Santiago de Compostela. Oxford: Clarendon Press.

FuCHS, D., J. GERHARDS and E. ROLLER, 1995. Nationalism versus Eurocentrism? The construction of collective identities in Western Europe. In M. Martiniello (ed.), Migration, Citizenship and Ethno-National Identities in the European Union: 165-178. Aldershot: Avebury. 
GIBBS, L.E., 1997. Forging a unique Spanish Christian identity: Santiago and El Cid in the Reconquista. The Student Historical Journal 1996-1997 28:2532.

Gitlitz, D.M. and L.K. Davidson, 2000. The Pilgrimage Road to Santiago: The Complete Cultural Handbook. New York: St Martin's Griffin.

Grabow, S., 2006. Culture Heritage Management Policy by the European Union: Reconciling Diversity and Inclusivity. Unpublished PhD thesis, University of York.

GRAHAM, B., 1998a. The past in Europe's present: diversity, identity and the construction of place. In B. Graham (ed.), Modern Europe: Place, Culture and Identity: 19-49. London: Arnold.

GRAHAM, B., 1998b. Europe's geographies: diversity and integration (epilogue). In B. Graham (ed.), Modern Europe: Place, Culture and Identity: 311-317. London: Arnold.

GrAHAM, B.J. and M. MurRAY, 1997. The spiritual and the profane: the pilgrimage to Santiago de Compostela. Ecumene 4(4): 389-409.

HADDAD, Y.Y., 1999. The globalization of Islam: the return of Muslims to the West. In J.L. Esposito (ed.), The Oxford History of Islam: 601-641. Oxford: Oxford University Press.

HarveY, L.P., 1990. Islamic Spain, 1250 to 1500. Chicago, IL: University of Chicago Press.

HefFernAn, R., 2001. Building the European Union. In S. Bromley (ed.), Governing the European Union: 27-52. London: SAGE.

HeINTZ, M., 2001. The citadel - a metaphor for the study of the European Union identity. Cambridge Anthropology 22(1): 37-49.

Huber, D., 1999. A Decade Which Made History - The Council of Europe 1989-1999. Strasbourg: Council of Europe.

KabBani, R., 2001. Letter to Christendom (3rd edn). Damascus: Virago Press.

KENNY, J., 2007. Visions of Europe: constructions of stereotype Europe and common 'heritage' landscapes. In S. Grabow, D. Hull and E. Waterton (eds), Which Past, Whose Future? Treatments of the Past at the Start of the 21st Century: 167-175. Oxford: British Archaeological Reports (International Series S1633).

Kofman, E. and R. SAlES, 1992. Towards fortress Europe? Women's Studies International Forum 15(1): 29-39.

KubiceK, P., 2003. The European Union and Democratization: Reluctant States. London: Routledge.

LuARD, N., 1998. To Santiago de Compostela: a journey of remembrance. In J.M. Fladmark (ed.), In Search of Heritage as Pilgrim or Tourist?: 77-89. Shaftesbury: Donhead.

Nugent, N., 1989. The Government and Politics of the European. Basingstoke: Macmillan.

PAASI, A., 2001. Europe as a social process and discourse - considerations of place, boundaries and identity. European Urban and Regional Studies 8(1): 7-28.

PANTEL, M., 1999. Unity-in-diversity: cultural policy and EU legitimacy. In T. Banchoff and M.P. Smith (eds), Legitimacy and the European Union: The Contested Polity: 46-65. London: Routledge.

SAID, E.W., 1978. Orientalism. Harmondsworth: Penguin.

SCHWIMmeR, W., 2003. The Council of Europe at the Dawn of the 21st Century. URL (consulted 29 June 2004): http:/ /www.coe.int/T/E/Com/About_Coe/ SGspeech.asp

STRÅTH, B., 2002. A European identity: to the historical limits of a concept, European Journal of Social Theory 5(4): 387-401. 
Thomas-PenetTe, M., 1999. Cultural Routes: key factors in the discovery of a common heritage. European Heritage 7: 7-10.

Thomas-Penette, M., 2003. Les itinéraires de pèlerinages et le tourisme culturel. In D. Péricard-Méa (ed.), Recontres sur les chemins de Saint-Jacques: 187-199. Anglet: Atlantica.

Wallace, W., 1990. The Transformation of Western Europe. London: Pinter.

WiLSON, K. and J. vAN DEN DUSSEN, 1993. The History of the Idea of Europe. London: Routledge.

ZEFF, E.E. and E.B. PIRRO, 2001. Introduction. In E.E. Zeff and E.B. Pirro (eds), The European Union and the Member States: Cooperation, Coordination, and Compromise: 1-6. London: Rynne Rienner.

\section{SUBMISSION DATA}

Received 12 March 2008; accepted 10 August 2008; revised 18 August 2009

\section{BIOGRAPHICAL NOTE}

Sven Grabow started his archaeological studies in Germany at the University of Saarbrücken but completed his undergraduate education in the UK at the University of York. At York he received his PhD in 2008 for a thesis on 'Culture Heritage Policy in the European Union: Reconciling Diversity and Inclusivity'. He has worked as a freelance archaeological illustrator, and has for several years taught illustration at the University of York. He co-organized the conference 'Which Past, Whose Future? Treatments of the Past at the Start of the 21st Century' and co-edited the resulting proceedings. Since then he has worked as a researcher and exhibition developer for a number of UK museums. He now lives and works in Wellington, New Zealand.

[email: fisher-king@web.de]

\section{Abstracts}

Les routes de pèlerinage de Saint -Jacques -de -Compostelle : vue critique du développement de la politique et pratique européennes du patrimoine culturel Sven Grabow

Se fondant sur l'exemple du projet des Itinéraires Culturels Européens du Conseil de l'Europe, cet article analyse si et à quel degré les rhétoriques supranationales d'ouverture culturelle, d'inclusivité et de diversité sont réalisées dans le sens de projets réels de patrimoine culturel. Dans ce contexte on examine de façon critique ce qui est considéré comme un des projets phares de patrimoine culturel européen supranational du Conseil de l'Europe, à savoir les chemins de pèlerinage de Saint-Jacques-de- Compostelle. L'attention est surtout portée sur l'implémentation spécifique du message supranational d'héritage culturel du Conseil de l'Europe dans ce projet et dans le guide l'accompagnant. En plaçant le projet dans son contexte historique et en le comparant à des adjonctions ultérieures du projet des Itinéraires Culturelles Européens, cet article réfléchit sur le développement d'un paradigme d'identité culturelle paneuropéenne au cours des deux dernières décennies. 
Mots clés : Conseil de l'Europe, patrimoine culturel, identité culturelle, politique culturelle, Institut Européen des Itinéraires Culturels, chemins de pèlerinage, St Jacques, St-Jacques-de Compostelle

(translation by Isabelle Kayser-Gerges)

Die Pilgerrouten nach Santiago de Compostela: Die Entwicklung europäischer Kulturerbestrategie und -praxis aus einer kritischen Perspektive

Sven Grabow

Der folgende Beitrag analysiert am Beispiel des „Europäische Kulturstraßen Projektes“ des Europarates ob und inwiefern supra-nationale Rhetorik der kulturellen Offenheit, Inklusivität und Vielfalt im Sinne von konkreten Kulturerbeprojekten in die Realität umgesetzt werden. Vor diesem Hintergrund wird eines der Flaggschiffe eurokratischer supra-nationaler Kulturerbeprojekte - das der Pilgerrouten nach Santiago de Compostela - kritisch untersucht. Der spezielle Fokus liegt in der konkreten Implementierung der kulturellen Botschaft im Sinne von Kulturdenkmälern, als auch im Zusammenhang der begleitenden Publikation in der Gestalt des projektspezifischen Reiseführers. Durch die Präsentation des Projektes im historischen Kontext und im Vergleich mit späteren Erweiterungen des Projektes, reflektiert dieser Beitrag über die Entwicklung paneuropäischer Identitätskonzepte während der letzten zwei Jahrzehnte.

Schlïsselbegriffe: Europarat, Kulturerbe, kulturelle Identität, Kulturstrategie, Europäisches Institut für Kulturrouten, Pilgerrouten, St. Jakob, Santiago de Compostela

(translation by Sven Grabow and Heiner Schwarzberg) 